\title{
ERCC2 Gene Mutation
}

National Cancer Institute

\section{Source}

National Cancer Institute. ERCC2 Gene Mutation. NCI Thesaurus. Code C131800.

A change in the nucleotide sequence of the ERCC2 gene. 